INVITED REVIEW

\title{
Biology of the gonadotropin-releasing hormone system in gynecological cancers
}

Carsten Gründker, Andreas R Günthert, Silke Westphalen and Günter Emons

Department of Gynecology and Obstetrics, Georg-August-University, D-37070 Göttingen, Germany

(Correspondence should be addressed to G Emons, Department of Obstetrics and Gynecology, Georg-August-University of Göttingen, Robert-Koch-Str. 40, D-37075 Göttingen, Germany; Email: emons@med.uni-goettingen.de)

\begin{abstract}
The expression of GnRH and its receptor as a part of an autocrine regulatory system of cell proliferation has been demonstrated in a number of human malignant tumors, including cancers of the breast, ovary and endometrium. Dose-dependent antiproliferative effects of GnRH agonists in cell lines derived from these cancers have been observed by various investigators. GnRH antagonists also have marked antiproliferative activity in most breast, ovarian and endometrial cancer cell lines tested, indicating that the dichotomy of GnRH agonists and antagonists might not apply to the GnRH system in cancer cells. The classical GnRH receptor signal-transduction mechanisms, known to operate in the pituitary, are not involved in the mediation of antiproliferative effects of GnRH analogs in cancer cells. Rather, the GnRH receptor interacts with the mitogenic signal transduction of growth factor receptors and related oncogene products associated with tyrosine kinase activity, via activation of a phosphotyrosine phosphatase, resulting in downregulation of cancer cell proliferation. In addition, GnRH activates nuclear factor $\kappa \mathrm{B}$ and protects the cancer cells from apoptosis. Furthermore, GnRH induces activation of the c-Jun N-terminal kinase/activator protein-1 (AP-1) pathway independent of the known AP-1 activators, protein kinase or mitogen activated protein kinase.
\end{abstract}

European Journal of Endocrinology 146 1-14

\section{Introduction}

\section{Hypothalamic gonadotropin-releasing hormone}

The hypothalamic decapeptide gonadotropin-releasing hormone $(\mathrm{GnRH})$, also called luteinizing hormone releasing hormone (LHRH), has an important role in the control of mammalian reproduction (1-3). It is released from the hypothalamus in a pulsatile manner and stimulates the synthesis and release of luteinizing hormone and follicle-stimulating hormone. In addition to this well-documented classic hypophysiotropic action, GnRH might have a role as a modulator of the activity of diverse systems in the brain and many peripheral organs (1, 4-10). An autocrine/paracrine function of $\mathrm{GnRH}$ has been suggested to exist, for instance, in the placenta (11-14), granulosa cells (15-17), myometrium (18) and lymphoid cells (19-21). In addition, it is probable that such GnRH-based autocrine systems are present in a number of human malignant tumors, including cancers of the breast, ovary, endometrium and prostate.

In this article, our present knowledge on the common features and the mechanisms of action of $\mathrm{GnRH}$ in human gynecological cancers will be reviewed. In addition, new knowledge on GnRH-II will be reported.

\section{The GnRH receptor}

GnRH binds to a specific GnRH receptor. Cloning of the GnRH receptor from several mammalian species (7, $22-28$ ) has revealed that the receptor is a member of the large superfamily of seven transmembrane domain receptors that bind to G-proteins $(7,29,30)$. Upon hormone binding, the GnRH receptor normally acts via pertussis toxin-insensitive G-proteins, most probably belonging to the G-protein $\alpha \mathrm{q}$ family (31). Through G-protein $\alpha q$, probably, phospholipases and calcium channels are activated as the next steps in signal transduction.

\section{GnRH receptors in human reproductive tissues}

There is growing evidence of auto- and paracrine GnRH systems in human reproductive tissues. In normal human extrapituitary tissues, including breast, placenta, endometrium, ovary and testis, controversial 
data have been obtained relating to the presence of GnRH receptors (5-7). Northern blot analysis failed to detect GnRH receptor mRNAs in any of the non-pituitary tissues examined (24). However, using RT-PCR, these mRNAs were recently identified in granulosa luteal cells (16). The GnRH receptor transcript was identical to that found in pituitary gonadotrophs (32). During spontaneous luteinization, GnRH and GnRH receptor expression were increased, suggesting that $\mathrm{GnRH}$ has a role in controlling corpus luteum function (32). Kang et al. (33) demonstrated activation of mitogenactivated protein kinase (MAPK) by GnRH agonists in granulosa luteal cells. Nathwani et al. (32) were able to demonstrate a downregulation of GnRH mRNA by estradiol and a biphasic effect of estradiol on GnRH receptor mRNA expression, with an initial stimulation and a secondary downregulation. In addition, regulation of estrogen receptors $\alpha$ and $\beta$ by GnRH agonists has been demonstrated, as the expression of both receptors is downregulated (34). The data published on the normal human ovary are controversial. Using RT-PCR, Ohno et al. (8) failed to detect GnRH receptor expression in the normal ovary. In contrast, Minaretzis et al. (17) detected GnRH receptor mRNA in 9 of 10 human ovaries, using RT-PCR. Srkalovic et al. (35) detected GnRH receptors in 54\% of normal human ovaries, by radioligand binding experiments. To date, the only functional data in this field are the experiments of Kang et al. (36). In human ovarian surface epithelium (hOSE) cell cultures, they demonstrated the existence of GnRH receptors and a biphasic antiproliferative effect of the GnRH agonist, [D-Ala $\left.{ }^{6}\right] \mathrm{GnRH}$. This effect was blocked by the GnRH antagonist, antide (36). In the normal human endometrium and myometrium, Reshkin et al. (37) demonstrated expression of a high percentage of GnRH receptors, by radioligand binding experiments. Using RT-PCR and Southern blot, Ikeda et al. (38) were able to demonstrate GnRH, but not GnRH receptors, in the endometrium and the decidua. In contrast, Raga et al. (39) detected $\mathrm{GnRH}$ and $\mathrm{GnRH}$ receptors in the endometrium by RT-PCR and immunohistochemistry. As a dynamic pattern was found, with increasing concentrations in the luteal phase, the authors suggested that GnRH may have a paracrine/autocrine role in the early stages of implantation by modulating trophoblastic secretion of human chorionic gonadotropin (39). Interestingly, similar findings were made in the Fallopian tube (40). GnRH receptors have even been detected in endometriosis: using RT-PCR and Southern blot, Borroni et al. (41) were able to demonstrate the presence of these receptors in 13 of 13 samples of ovarian endometriosis; however, in cell cultures of these lesions, the GnRH agonist, leuporelin, exerted antiproliferative effects in just 5 of 13 cases. Kottler et al. (42) demonstrated co-expression of $\mathrm{GnRH}$ and its receptor in malignant and non-malignant tissues of the human breast. As GnRH agonists inhibit breast epithelial cell growth, these data raise the possibility of an autocrine/paracrine role for GnRH in the human mammary gland (42).

To summarize: the expression of GnRH and of GnRH receptors, in addition to autocrine and paracrine effects of GnRH, have been shown in several benign reproductive tissues. In contrast to the situation with respect to the pituitary and the gynecologic tumors, the physiological role of these receptors is only marginally elucidated. Further understanding in this field might improve both reproductive medicine and the understanding of tumor biology.

\section{GnRH in human gynecological cancers}

\section{Expression of GnRH and GnRH receptors}

In earlier studies it was shown that breast, ovarian and endometrial cancers express receptors for $\mathrm{GnRH}(1,2$, 4, 43-45). Two types of GnRH binding sites exist, one of low affinity and high capacity, the other of high affinity and low capacity. The latter is comparable to the pituitary GnRH receptor $(4,46,47)$. In 1992, cloning, sequencing and expression of the human pituitary GnRH receptor were reported $(23,24)$. These findings stimulated intensive research, leading to the demonstration of $\mathrm{GnRH}$ receptor gene transcripts in ovarian and endometrial cancer cell lines and in about $80 \%$ of the respective primary tumors $(23,48-50)$ (Table 1). In ovarian and endometrial cancer specimens and cell lines expressing mRNA for the pituitary GnRH receptor, high-affinity/low-capacity binding sites were found in

Table 1 Expression of $\mathrm{GnRH}$ and $\mathrm{GnRH}$ receptors ( $\mathrm{GnRH}-\mathrm{R})$, and biological effects of $\mathrm{GnRH}$ analogs. Data were obtained in primary cancer, respective tumor cell lines, or both. Numbers in parentheses indicate the available data on percentages of primary cancers expressing GnRH, GnRH-R or the respective mRNAs. For details and references, see text. From Emons et al. (60), with permission. (c) 1997 Elsevier Science.

\begin{tabular}{|c|c|c|c|c|c|c|}
\hline \multirow[b]{2}{*}{ Tumor type } & \multicolumn{2}{|c|}{ Expression of GnRH } & \multicolumn{2}{|c|}{ Expression of GnRH-R } & \multicolumn{2}{|c|}{ Inhibitory effects of GnRH analogs } \\
\hline & Immuno/bioactivity & mRNA & Radioreceptor assay & mRNA & Proliferation & Mitogenic signal transductiom \\
\hline Breast cancer & + & + & $+(>50 \%)$ & + & + & + \\
\hline Ovarian cancer & $+(>80 \%)$ & $+(>80 \%)$ & $+(>80 \%)$ & $+(>80 \%)$ & + & + \\
\hline Endometrial cancer & $+(>80 \%)$ & $+(>80 \%)$ & $+(>80 \%)$ & $+(>80 \%)$ & + & + \\
\hline
\end{tabular}


close relation to the pituitary GnRH receptor (48-52). Kakar et al. (25) demonstrated that the nucleotide sequence of $\mathrm{GnRH}$ receptors in human breast and ovarian tumors is identical with that found in pituitary. Data available today suggest that about $50 \%$ of breast cancers (53) and approximately $80 \%$ of ovarian and endometrial cancers express high-affinity binding sites for GnRH. For prostate cancer, fewer findings have been published (46), but systematic investigations might lead to comparable results.

Harris et al. (54) reported the expression of the mRNA for GnRH in two human breast carcinoma cell lines. Recently, two groups independently demonstrated GnRH immunoreactivity and bioactivity, and the expression of mRNA for GnRH by cell lines and in the majority of biopsy samples of ovarian and endometrial cancers $(50,55,56)$. As breast, ovarian and endometrial cancers express GnRH and its receptor, it seems reasonable to speculate that, in many of these tumors, there is a local regulatory system based on $\mathrm{GnRH}$. The same situation was found in prostate cancer cells (45).

\section{Direct antitumor effects of GnRH analogs}

The in vitro proliferation of a variety of human cancer cell lines can be inhibited by agonistic or antagonistic analogs (or both) of GnRH in a dose- and time-dependent manner $(4,47,51,52,57-59)$ (Fig. 1). In most cancer cells except for the ovarian cancer cell line EFO-27, GnRH antagonists act like agonists, indicating that the dichotomy of GnRH agonists and antagonists does not exist in tumor cells $(51,60)$. Using the human ovarian cancer cell line OV-1063 xenografted into nude mice, Yano et al. (61) demonstrated a signifi- cant inhibition of tumor growth by chronic treatment with the GnRH antagonist, cetrorelix, but not with the GnRH agonist, triptorelin. As both GnRH analogs induced a comparable suppression of the pituitarygonadal axis, the authors speculated that in vivo antitumor effects of cetrorelix were exerted directly on GnRH receptors in tumors (62). The findings on direct antitumor effects of GnRH analogs in ovarian and endometrial cancer reported by several other groups are completely or partly in agreement with those described earlier $(47,62-64)$. In contrast, other investigators failed to detect direct antitumor effects of GnRH analogs in human ovarian and endometrial cancer cell lines, or observed them only at extremely high concentrations of GnRH analog (65-67). These discrepancies might be explained by the likelihood that the majority of the cell lines used by these authors did not express highaffinity GnRH receptors $(47,68)$. Alternatively, differences in culture or experimental conditions and in the types of GnRH analogs used might be responsible for the observed variance. In the case of prostate cancer, several groups reported direct antiproliferative effects of GnRH analogs in vitro and in animal in vivo models, which could be mediated through specific GnRH-binding sites $(1,46,69-73)$.

Proliferation of ovarian cancer cells was significantly increased after treatment with an antiserum to GnRH, suggesting that GnRH produced by human ovarian cancer cells acts as a negative autocrine regulator of proliferation (74) (Fig. 2). In contrast, Arencibia \& Schally (75) have recently reported that, in ES-2 human ovarian cancer cells, the GnRH agonist triptorelin in a concentration of $10 \mathrm{ng} / \mathrm{ml}$ stimulated the proliferation in vitro after $48 \mathrm{~h}$, but was inhibitory after $72 \mathrm{~h}$ and in concentrations of $1000 \mathrm{ng} / \mathrm{ml}$. The $\mathrm{GnRH}$
Ishikawa : Triptorelin

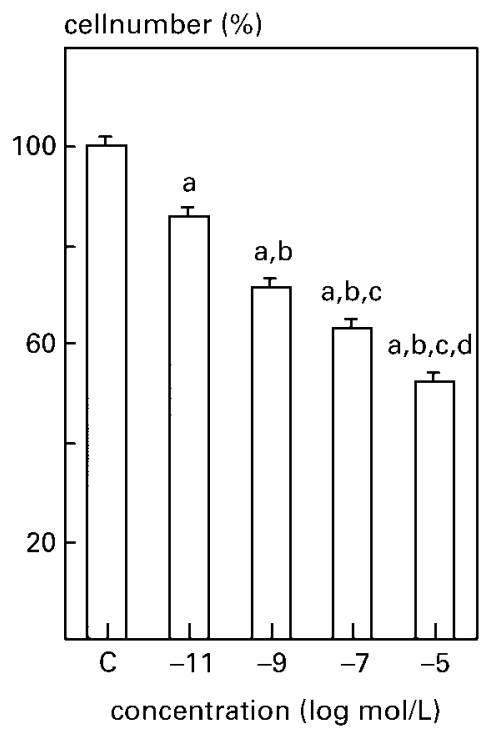

Ishikawa : Cetrorelix

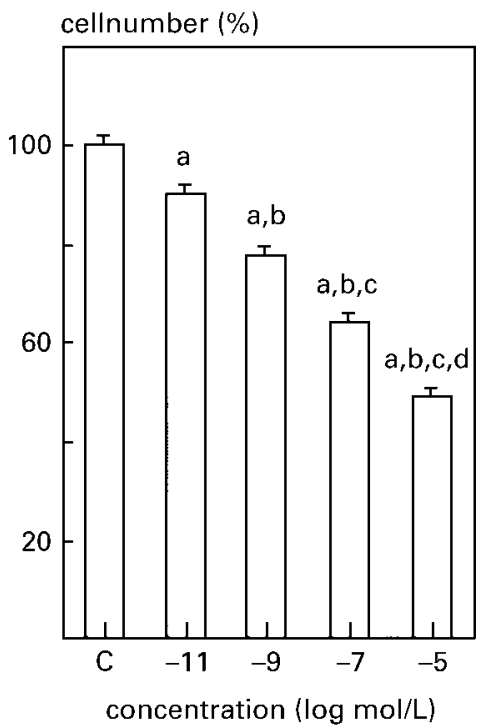

Figure 1 Effects of 6 days of treatment with increasing concentrations of $\mathrm{GnRH}$ agonist triptorelin (left panel) or antagonist cetrorelix (right panel) on the proliferation of the endometrial cancer cell line, Ishikawa. Cell number is expressed as percent of the control (C; vehicle only $=100 \%$ ). Each column represents the mean \pm S.E. of data obtained from three (triptorelin) or four (cetrorelix) independent experiments run in quadruplicate in three or four different passages of the cell line. Analysis of variance: $P<0.001$. Significant differences $(P<0.01)$ compared with: ${ }^{a}$ Control; ${ }^{b} 10^{-11} \mathrm{~mol} / / ;{ }^{c} 10^{-9} \mathrm{~mol} / / ;{ }^{\mathrm{d}} 10^{-7} \mathrm{~mol} / \mathrm{l}$ (Newman-Keuls test). Experiments using endometrial cancer cell line $\mathrm{Hec}-1 \mathrm{~A}$ and ovarian cancer cell line EFO-21 gave comparable results. From Emons et al. (52), with permission. (C) 1993 The Endocrine Society. 


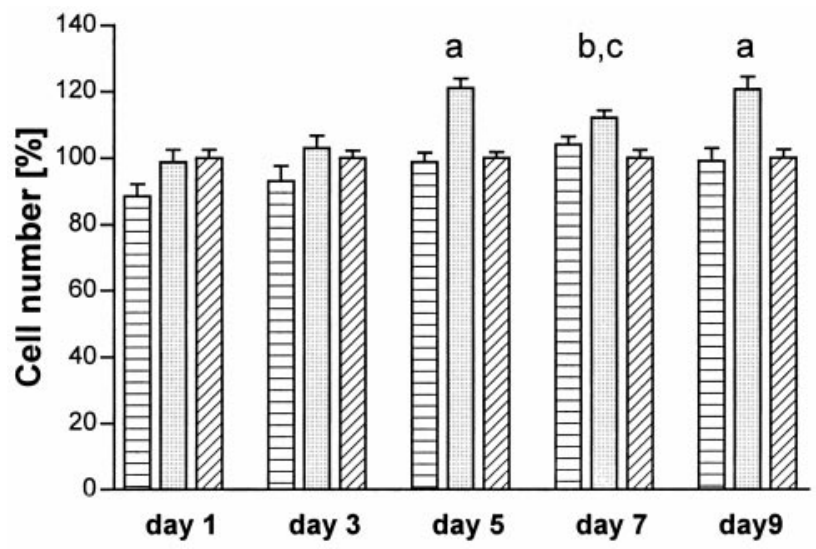

Figure 2 Time-course experiments of proliferation of the human ovarian cancer cell line EFO-21 in the presence of an antiserum against known $\mathrm{GnRH}$. Cells were incubated with normal rabbit serum (left bars) or with anti-GnRH antiserum (middle bars) or without rabbit serum (right bars). Cell number is given as a percentage of the controls $(100 \%)$. The bars represent the mean \pm S.E.M. of three independent experiments, carried out using different passages of the cell line in quadruple determinations. a $P<0.001$ compared with control and normal rabbit serum; ${ }^{\mathrm{b}} P<0.01$ compared with control; ${ }^{\mathrm{c}} P<0.05$ compared with normal rabbit serum. From Emons et al. (74), with permission. (c) 2000 Society of the European Journal of Endocrinology.

antagonist cetrorelix inhibited growth of the ES-2 cell line only in a concentration of $1000 \mathrm{ng} / \mathrm{ml}$. The in vitro incubation of ES-2 ovarian cancer cells with an GnRH antibody inhibited cell proliferation in a timeand concentration-dependent manner. These results suggest that GnRH may function as an autocrine growth factor in this ovarian cancer cell line (75). Differences between tumor cell lines (e.g. variances in G-protein coupling and signaling) might explain these discrepancies.

\section{Molecular mechanisms mediating the direct antitumor effects of GnRH}

In view of the apparent similarity of GnRH receptors in peripheral cancers to those in the pituitary gonadotrophs, it seemed reasonable to speculate that GnRH signal transduction pathways in tumors might also be comparable to those operating in the pituitary, such as phospholipase C (PLC) and protein kinase C (PKC). Our group performed extensive studies in human ovarian and endometrial cancer cell lines. These cell lines express GnRH and GnRH receptors, and their proliferation is inhibited by GnRH analogs (50-52). Although we were able to demonstrate clearly the activation of PLC, PKC and adenylyl cyclase in these tumor cells by pharmacological stimuli, the GnRH agonist triptorelin, in concentrations that were inhibitory to proliferation, had no effects on the activity of these signaling systems (76). We found, however, that the mitogenic effect of growth factors in these cell lines could be counteracted by triptorelin, indicating an interaction with the mitogenic signal transduction pathway (76). Comparable data were obtained by Moretti et al. (77) in the human prostatic cancer cell lines LNCaP and DU 145. These findings were in accord with reports that GnRH analogs reduced expression of growth factor receptors and their mRNA $(61,77,78)$ or growth-factor-induced tyrosine kinase activity, or both $(76,77,79-84)$. Growth-factor-induced tyrosine phosphorylation is probably counteracted by GnRH analogs through activation of a phosphotyrosine phosphatase (PTP) (76, $77,80,81,83,84)$, which is probably coupled to the GnRH receptor through a G-protein $\alpha$ i in human reproductive tract tumors (85). Using an antibody against tyrosine phosphate, we were able to show that the GnRH agonist triptorelin and the antagonist cetrorelix reduce epidermal growth factor (EGF)-induced tyrosine auto-phosphorylation of EGF receptors to $60-80 \%$ of that in controls. This effect was completely inhibited using the phosphatase inhibitor, vanadate (86) (Fig. 3).

The concept of an inhibition of mitogenic signal transduction by GnRH analogs in human cancer cells was further corroborated by our group. We demonstrated that EGF-induced activation of MAPK, an enzyme further downstream in the growth factor signaling cascade (87), was virtually completely blocked in ovarian and endometrial cancer cells treated with the GnRH agonist triptorelin (76). By quantitative RT-PCR and western blotting, we showed that the EGF-induced expression of the immediate early gene $c$-fos, a mechanism still further downstream in mitogenic signaling, was completely abrogated in breast, ovarian and endometrial cancer cells by treatment with the GnRH agonist triptorelin or with the GnRH antagonist cetrorelix (88) (Fig. 4). The same effects were seen by Motta's group in the prostatic cancer cell line LNCaP by treatment with the GnRH agonist, goserelin $(77,89)$.

The reasons for the differences in GnRH signal transduction in the pituitary gonadotroph and peripheral cancers remain unclear. Experimentally induced mutations of the GnRH receptor have altered $\mathrm{GnRH}$ binding, G-protein-receptor interactions, or correct membrane incorporation (90-96). However, in none of the analyzed breast, endometrial and ovarian cancer cell lines were we able to find any mutation in the coding region of the GnRH receptor gene transcripts (86). Therefore mutations or splice variants of the GnRH receptor cannot be responsible for the alternative GnRH signal transduction pathway in cancer cells (86). Conversely, some normal and neoplastic human tissues have been found to express differential splice variants of the GnRH receptor gene in a tissue-dependent manner (97). It is not clear yet whether these splice variants can be translated into active membrane receptors or not. In the tumor cell lines that we analyzed, however, no signs of alternative GnRH receptor splice variants were seen (86). 

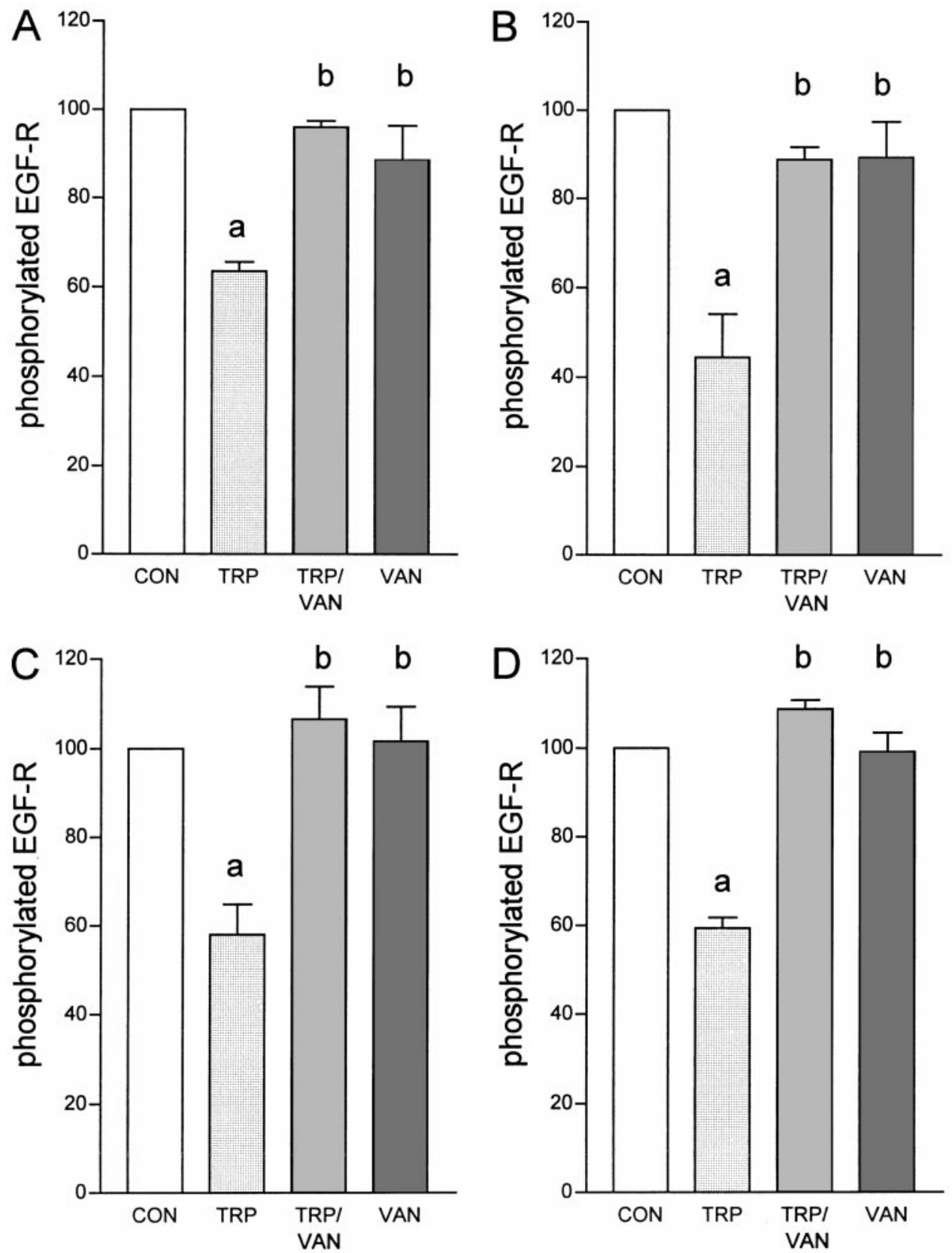

Figure 3 Quantification of tyrosine-phosphorylated EGF receptors (EGF-R) by quantitative Western blotting of membranes obtained from the ovarian cancer cell lines EFO-21 (A) and EFO-27 (B) and endometrial cancer cell lines Ishikawa (C) and Hec-1A (D). In the absense of EGF, no phosphorylated EGF-Rs were detectable. Relative changes in the amounts of phosphorylated EGF-Rs after treatment with EGF $(100 \mathrm{nmol} / \mathrm{l})$ are given in the absence $(\mathrm{CON}=100 \%)$ or presence $(\mathrm{TRP})$ of the $\mathrm{GnRH}$ agonist triptorelin $(10 \mu \mathrm{mol} / \mathrm{l})$ with or without vanadate (VAN). Columns represent means \pm S.E. of data obtained from three independent experiments run in duplicate in three different passages of each cell line. Significant differences $(P<0.001)$ compared with ${ }^{\mathrm{a}}$ control; ${ }^{\mathrm{b}} \mathrm{TRP}$. From Gründker et al. (86), with permission. (c) 2001 The Endocrine Society.

It might be possible that a different coupling to Gproteins is responsible for the distinct GnRH signal transduction in cancer cells as compared with pituitary gonadotrophs. We found that, in endometrial and ovarian cancer cells, the GnRH receptor couples to several G-proteins (G-protein $\alpha \mathrm{q}$ and G-protein $\alpha \mathrm{i}$ ) (Fig. 5).
The antiproliferative signal transduction, however, is exclusively mediated through the pertussis toxin-sensitive G-protein $\alpha \mathrm{i}(86)$ (Fig. 6).

It has been speculated that GnRH activates a PTP and thus antagonizes growth-factor-induced tyrosine phosphorylation (60). It is likely that the antiproliferative 


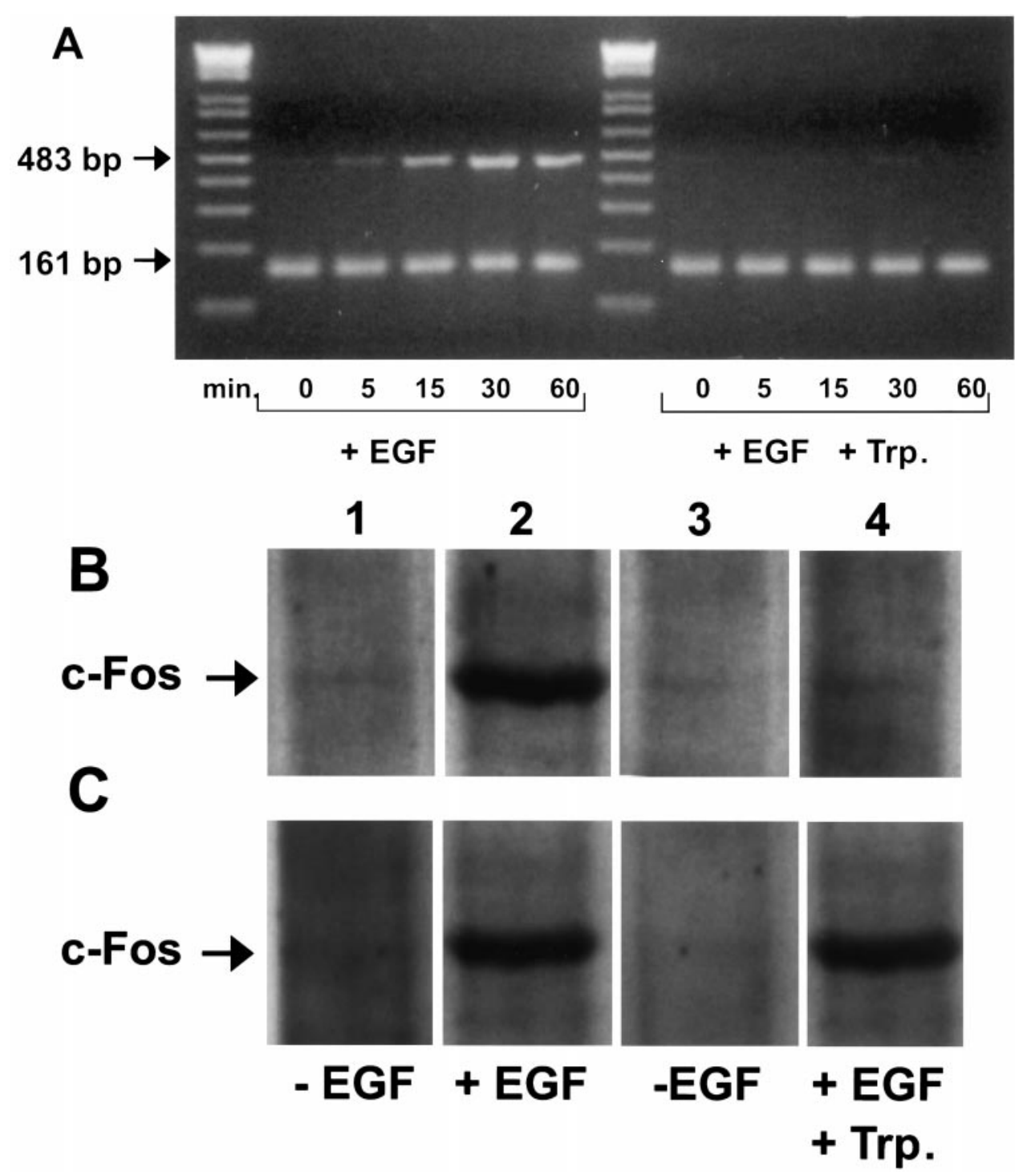

Figure 4 (A) PCR amplification of first-strand cDNA from the ovarian cancer cell line EFO-21. Oligonucleotide primers for human $c$-fos were used. Gel was stained with ethidium bromide, and bands were visualized with UV light. Upper bands represent $c$-fos amplification, lower bands represent internal standard amplification. Quiescent cells were incubated in the absence or presence $(+\operatorname{Trp}$.) of the GnRH agonist triptorelin (100 nmol/l) for $15 \mathrm{~min}$, followed by treatment with $100 \mathrm{nmol} / \mathrm{I} \mathrm{EGF} \mathrm{for} 10 \mathrm{~min}$. (B) and (C) Immunoblotting of c-Fos protein in ovarian cancer cell lines EFO-21 (B) and SK-OV-3 (C) using a polyclonal rabbit anti human c-Fos antibody. Quiescent cells were kept for $15 \mathrm{~min}$ in the absence or presence of the $\mathrm{GnRH}$ agonist triptorelin $(100 \mathrm{nmol} / \mathrm{l})$ before being incubated for $10 \mathrm{~min}$ with $100 \mathrm{nmol} / \mathrm{l}$ EGF. The amount of c-Fos protein was very small in the serum-starved cells (lane 1), but increased strongly after EGF treatment (lane 2). In the ovarian cancer cell line EFO-21, EGF-induced c-Fos protein synthesis was inhibited by the GnRH agonist triptorelin (B, lanes 3 and 4). In the ovarian cancer cell line SK-OV-3, which does not express GnRH receptors, GnRH agonists or antagonists had no effects on the EGF-induced c-Fos protein synthesis (C, lanes 3 and 4). From Gründker et al. (88), with permission. (c) 2000 Academic Press.

effects of GnRH analogs might be directly mediated through inhibition of growth factor signaling on its first step, the auto-phosphorylation of tyrosine residues of growth factor receptors. Some indirect evidence that GnRH activates a PTP was found by Imai et al. (83) and by Emons et al. (76), showing that GnRH reduces the net tyrosine phosphorylation of membrane proteins. Direct evidence for the G-protein $\alpha \mathrm{i}$-mediated activation of a PTP and a reduction in EGF receptor tyrosine phosphorylation by GnRH had not been obtained to date. We recently found that, in endometrial and ovarian cancer cells, the GnRH receptor activates a PTP, counteracting EGF-induced tyrosine auto-phosphorylation of the EGF receptor, resulting in downregulation of mitogenic signal transduction and cell proliferation. This effect was completely blocked by pertussis toxin, indicating the involvement of pertussis toxin-sensitive G-protein $\alpha$ i in GnRH-induced PTP activity (86) (Fig. 7). 

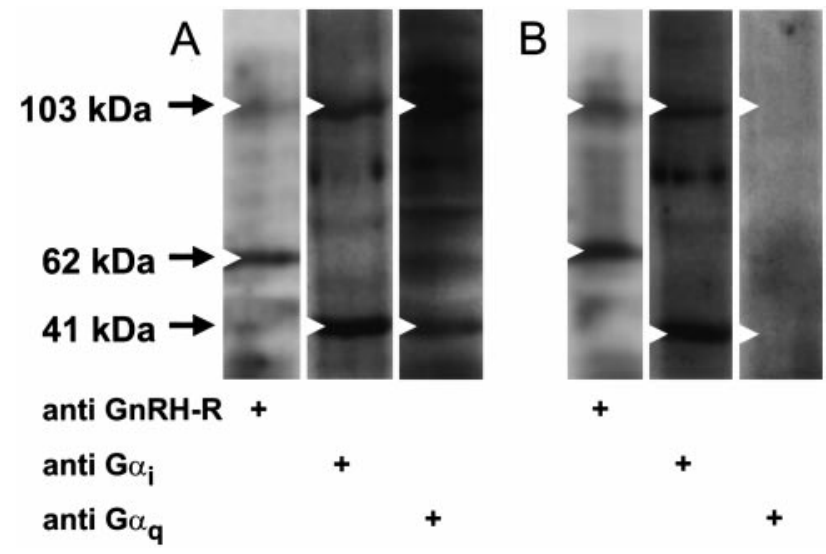

Figure 5 Crosslinking of G-protein $\alpha$ subunits and $\mathrm{GnRH}$ receptor in the ovarian cancer cell lines EFO-21 (A) and EFO-27 (B). Left lanes: Detection of the $\mathrm{GnRH}$ receptor protein $(62 \mathrm{kDa})$ and the crosslinked $\mathrm{GnRH}$ receptor-G-protein $\alpha$ complex using an anti$\mathrm{GnRH}$ receptor antibody (anti $\mathrm{GnRH}-\mathrm{R}$ ) (116). Middle lanes: Detection of G-protein $\alpha i$ and crosslinked GnRH receptor-Gprotein $\alpha$ i complex using an anti-G-protein $\alpha \mathrm{i}$ antibody (anti $\mathrm{G} \alpha_{\mathrm{i}}$ ). Right lanes: Detection of G-protein $\alpha q$ and crosslinked $\mathrm{GnRH}$ receptor-G-protein $\alpha q$ complex using an anti-G-protein $\alpha q$ antibody $\left(\right.$ anti $\left.G \alpha_{q}\right)$. Assuming a stoichiometric binding of 1:1, subtraction of the molecular weight of G-protein $\alpha \mathrm{i}(41 \mathrm{kDa})$ or G-protein $\alpha \mathrm{q}(41 \mathrm{kDa})$ from the crosslinked complex (103kDa) yielded a protein of about $62 \mathrm{kDa}$. This corresponds to the molecular weight of $\mathrm{GnRH}$ receptor. Both G-protein $\alpha$ i and $\alpha q$ were found to be crosslinked to $\mathrm{GnRH}$ receptor in the ovarian cancer cell line EFO-21 (A). In the EFO-27 cell line, which does not express G-protein $\alpha \mathrm{q}$, only G-protein $\alpha$ i was found to be crosslinked to $\mathrm{GnRH}$ receptor $(\mathrm{B})$. The figure shown is representative of three independent experiments run in duplicate in three different passages of the cell lines that gave identical results. Experiments using endometrial cancer cell lines Hec-1A or Ishikawa gave results identical to those with the ovarian cancer cell line EFO-21. From Gründker et al. (86), with permission. (C) 2001 The Endocrine Society.

\section{GnRH and apoptosis}

In plasma membranes of specimens from ovarian and endometrial cancers, GnRH recently has been shown to increase the expression of Fas ligand (98), known to promote apoptotic cell death through binding to Fas-positive cells within tumors. GnRH analogs are able to induce Fas ligand production in some GnRHreceptor-positive ovarian and endometrial cancer cells $(99,100)$. Though we have tried to show induction of apoptosis by GnRH analogs, we have found it only in one ovarian cell line ( $\mathrm{Ca}-\mathrm{Ov}-3)$, among nine ovarian (EFO-21, EFO-27, NIH:OVCAR-3, AN-3-CA, Ca-Ov-3, SK-OV-3) and endometrial (HEC-1A, HEC-1B, Ishikawa) cell lines investigated (101 and unpublished results). In a study conducted to investigate whether GnRH affects apoptosis in ovarian cancer, we found that the GnRH agonist triptorelin reduced apoptosis induced by the cytotoxic agent, doxorubicin. As triptorelin-induced reduction of doxorubicin-induced apoptosis was blocked by inhibition of nuclear factor $\kappa \mathrm{B}(\mathrm{NF} \kappa \mathrm{B})$ translocation into the nucleus, and triptorelin was shown to induce

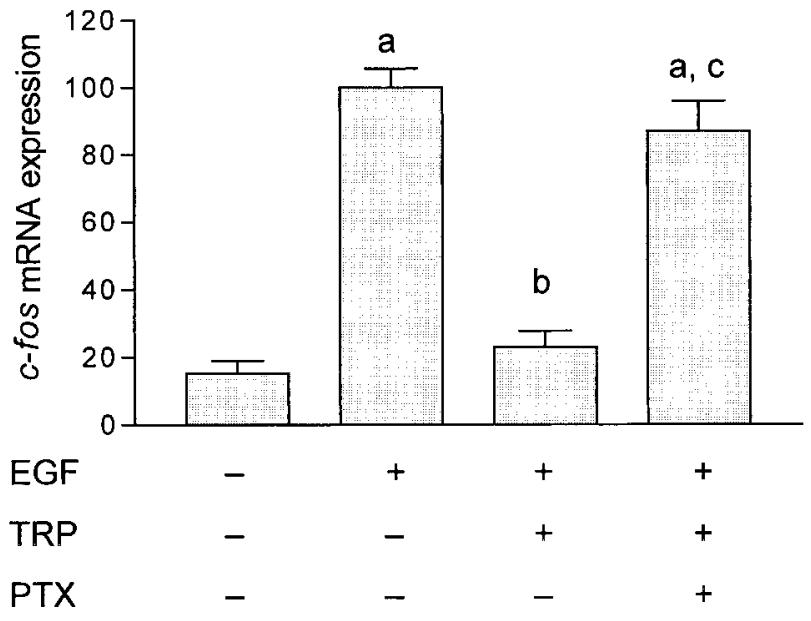

Figure 6 Effects of pertussis toxin (PTX) on the GnRH agonist triptorelin (TRP)-induced inhibition of EGF-induced $c$-fos expression. $c$-fos expression of quiescent EFO-21 ovarian cancer cells (first bar $=$ control) and after treatment with $100 \mathrm{nmol} / \mathrm{l} \mathrm{EGF}$ (10 min) without (second bar) or with (third bar) previous treatment (15 min) with the $\mathrm{GnRH}$ agonist triptorelin $(100 \mathrm{nmol} / \mathrm{l})$ or with previous treatment with the $\mathrm{GnRH}$ agonist triptorelin and with $2 \mathrm{ng} / \mathrm{ml}$ PTX (fourth bar). After treatment with EGF, a significant increase in $c$-fos expression was observed $(P<0.001)$ (second bar). After treatment with triptorelin followed by EGF, no increase in $c$-fos expression was observed (third bar). After treatment with pertussis toxin, triptorelin-induced inhibition of EGF-induced $c$-fos expression was blocked $(P<0.001)$ (fourth bar). Columns represent means \pm S.E. of data obtained from four independent experiments run in duplicate in four different passages of each cell line. Experiments using endometrial cancer cell lines Hec-1A or Ishikawa or the ovarian cancer cell line EFO-27 gave similar results. Significant differences $(P<0.001)$ compared with ${ }^{a}$ control; ${ }^{b} \mathrm{EGF} ;{ }^{\circ} \mathrm{EGF} / T R P$. From Gründker et al. (86), with permission. (C) 2001 The Endocrine Society.

$\mathrm{NF} \kappa \mathrm{B}$ activation, we concluded that GnRH has an antiapoptotic effect mediated through $\mathrm{NF} \kappa \mathrm{B}$ activation in these human ovarian cancer cells (101) (Fig. 8). This possible protection of ovarian cancer cells from programmed cell death that this offers is a new and important feature in GnRH signaling in ovarian tumors, in addition to its inhibitory interference with the mitogenic pathway.

\section{Additional signaling mechanisms}

In human endometrial and ovarian cancer cells, the GnRH agonist triptorelin stimulates the activity of activator protein-1 (AP-1) mediated through the pertussis toxin-sensitive G-protein $\alpha \mathrm{i}$. In addition, triptorelin activates c-Jun N-terminal kinase (JNK), which is known to activate AP-1 (102). In earlier investigations, we have shown that triptorelin does not activate PLC and PKC in endometrial and ovarian cancer cells (76). In addition, it has been demonstrated that triptorelin inhibits growth-factor-induced MAPK activity (76). Thus triptorelin-induced activation of the JNK/AP-1 pathway 

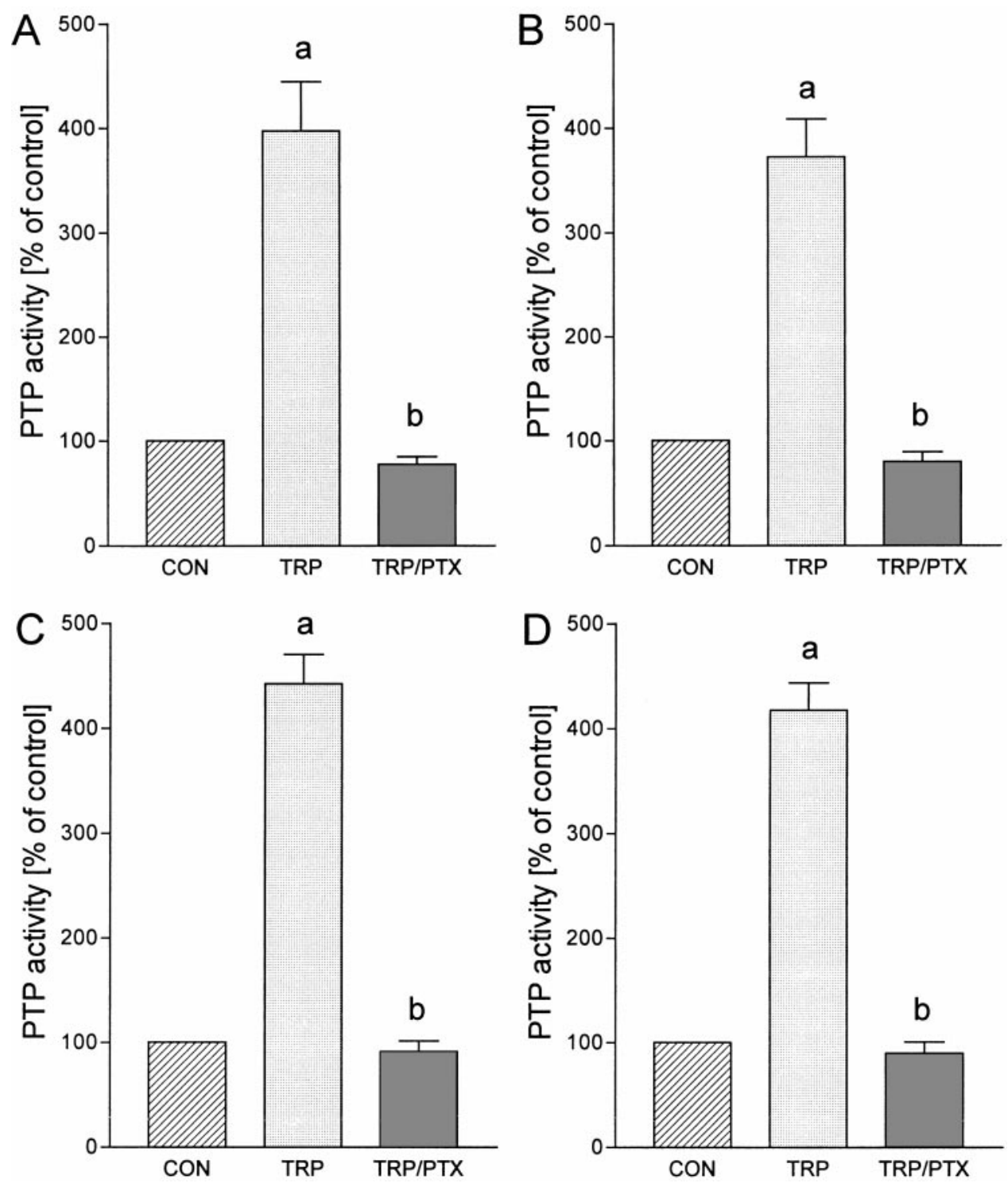

Figure 7 Effects of the GnRH agonist triptorelin (TRP) on PTP activity of EFO-21 (A) and EFO-27 (B) ovarian cancer cells and of Ishikawa (C) and Hec-1A (D) endometrial cancer cells. Quiescent cells were incubated for 15 min in the absence (control, CON) or presence of triptorelin with or without pertussis toxin (PTX), before PTP activity was measured. PTP activity is expressed as a percentage of controls (control $=$ no treatment $=100 \%$ ). Columns represent means \pm s. E. of data obtained from three independent experiments run in duplicate in three different passages of each cell line. Significant differences $(P<0.001)$ compared with ${ }^{\mathrm{a}}$ control; ${ }^{\mathrm{b}} \mathrm{TRP}$. From Gründker et al. (86), with permission. (c) 2001 The Endocrine Society.

in endometrial cancer cells is independent of the known AP-1 activators, PKC or MAPK.

In endometrial and ovarian cancer cells, GnRH analogs mediate antiproliferative actions via inhibition of growth-factor-induced mitogenic signal transduction. The GnRH agonist triptorelin protects the cancer cells from apoptosis via activation of $\mathrm{NF} \kappa \mathrm{B}$, and triptorelin stimulates AP-1 and JNK activity. Recently Yamauchi et al. (103) found that JNK is involved in inhibition of the cell proliferation that is induced by $\alpha 1 \mathrm{~B}$-adrenergic receptor in human embryonic kidney cells. In a study in rats, $c$-jun mRNA depression and endometrial epithelial cell proliferation were suggested to be linked (104). In
UT-OC-3 ovarian cancer cells, cytokines have inhibitory effects on cell proliferation and activate AP-1 and NFкB (105). As the antiproliferative GnRH agonist triptorelin activates the $\mathrm{JNK} / c$-jun pathway and $\mathrm{JNK} / c$-jun was found to be involved in downregulation of cell proliferation in different systems, it seems reasonable to speculate that the JNK/c-jun pathway is involved in the antiproliferative actions of the GnRH agonist triptorelin. It might be interesting to investigate the basis of the cooperation of AP-1 with NFkB, in addition to the molecular basis of the antiapoptotic functions. Further investigations are required to determine whether or not the triptorelin-induced increase in AP-1 activity is 

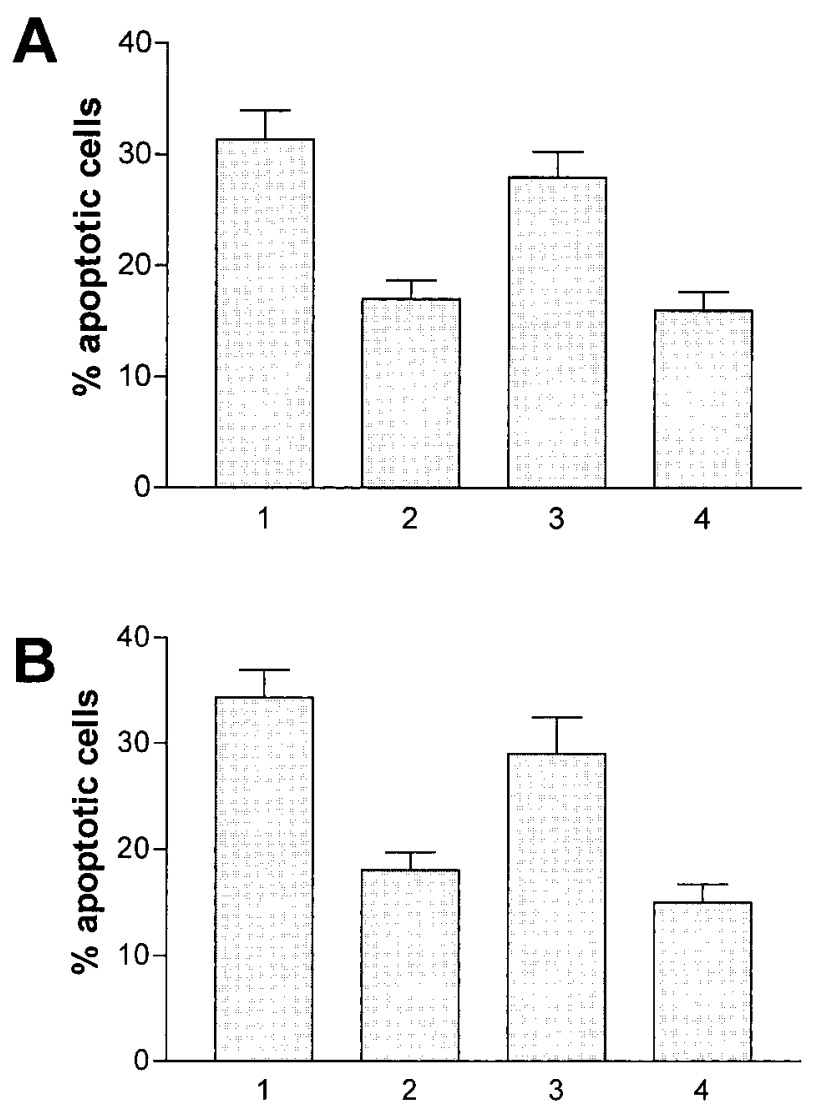

Figure 8 Flow cytometric analysis of ovarian cancer cell lines EFO-21 (A) and EFO-27 (B). After $72 \mathrm{~h}$ of treatment with $1 \mathrm{nmol} / \mathrm{l}$ of the cytotoxic agent doxorubicin, characteristic apoptotic DNA degradation ( $31 \%$ or $34 \%$ respectively) was observed (column 1 ). After $72 \mathrm{~h}$ of treatment with $1 \mathrm{nmol} / \mathrm{l}$ doxorubicin in the presence of $100 \mathrm{nmol} / \mathrm{l}$ of the $\mathrm{GnRH}$ agonist triptorelin, a significantly lower amount of characteristic apoptotic DNA degradation (17\% or $18 \%$ respectively) was observed $(P<0.001)$ (column 2). After $72 \mathrm{~h}$ of treatment with $1 \mathrm{nmol} / /$ doxorubicin and $100 \mathrm{nmol} / /$ triptorelin in the presence of $18 \mu \mathrm{mol} / \mathrm{I} \mathrm{NF} \kappa \mathrm{B}$ nuclear translocation inhibitor SN50, the proportion of cells showing characteristic apoptotic DNA degradation was $28 \%$ or $31 \%$ respectively (column 3 ). Using the inactive SN50M control peptide instead of SN50, a significantly lower amount of characteristic apoptotic DNA degradation (16\% or $15 \%$ respectively) was observed $(P<0.001)$ (column 4$)$. From Gründker et al. (101), with permission. (c) 2000 The Endocrine Society.

involved in the antiproliferative action of GnRH analogs, possibly via increasing the percentage of cells in the G0/ G1 phase of the cell cycle.

Imai et al. (106) recently found that, in membranes of ovarian cancer cells obtained from surgically removed ovarian tumors, lysophosphatidic acid was hydrolyzed by GnRH-induced activation of lysophosphatidic acid phosphatase.

\section{GnRH-II and its receptor}

In non-mammalian vertebrates, it became evident that three structural variants of GnRH were present in individual species $(107,108)$. A similar situation seems to exist in mammals. One of these GnRH variants is GnRH-II (also called chicken GnRH-II), which is entirely conserved in structure in the evolution from fish to mammals $(109,110)$. In human granulosaluteal cells, expression of GnRH-II has been found (111). In these cells, GnRH-I agonists exerted a biphasic effect on GnRH-I receptor density, whereas GnRH-II agonists just produced a downregulation of GnRH-I receptor expression and of GnRH-II (111). In human ovarian and endometrial tumor cells, we found that treatment with GnRH-II had much greater effects on the inhibition of tumor cell proliferation than GnRH-I and its agonists (unpublished results). In earlier studies, we were able to show that two types of GnRH binding sites exist in endometrial and ovarian cancer cells, one of low affinity and high capacity, the other of high affinity and low capacity. The latter is comparable to the pituitary GnRH receptor $(4,46,51,52)$. The low-affinity binding site (using GnRH-I agonists) may be the putative GnRH-II binding site, with GnRH-I cross-reaction. It could be speculated that a second GnRH receptor type would also be present in vertebrates. Neill et al. (112) cloned, from the rhesus monkey (Macaca mulatta ), a type II GnRH receptor that is highly selective for GnRH-II and was found to be ubiquitously expressed in human tissues, using a ${ }^{32} \mathrm{P}$-labeled riboprobe specific for GnRH-II receptor. As the type II receptor has a C-terminal cytoplasmatic tail, it is rapidly internalized, in contrast to the type I receptor, and has a distinctly different signaling pathway $(113,114)$. In addition, GnRH antagonists have agonistic effects on the type II receptor (115). This finding might explain earlier observations that $\mathrm{GnRH}$ antagonists behave like agonists in reproductive tissue tumors (60). The recent cloning of the primate type II GnRH receptor sets the stage for the development of new analogs with selective activities on either GnRH-I or GnRH-II systems.

\section{Summary}

In human cancers, the distinction between GnRH agonists and antagonists on the basis of pituitary responses may not be appropriate. In addition, the GnRH signal transduction pathway that operates in normal tissues seems not to be essential in cancer cells. The most important features of $\mathrm{GnRH}$ signaling in tumors are the inhibitory interference with the mitogenic pathway that results in antiproliferative actions, and the possibility of protecting the cells from apoptosis via activation of NFкB. In addition, GnRH activates the AP-1 signaling pathway which is possibly involved in the antiapoptotic and antiproliferative functions. In endometrial and ovarian cancer cells, the GnRH receptor couples to G-protein $\alpha \mathrm{q}$ and G-protein $\alpha \mathrm{i}$, but both the antiproliferative and the antiapoptotic signal transduction are mediated through G-protein $\alpha \mathrm{i}$. In prostate cancers, 


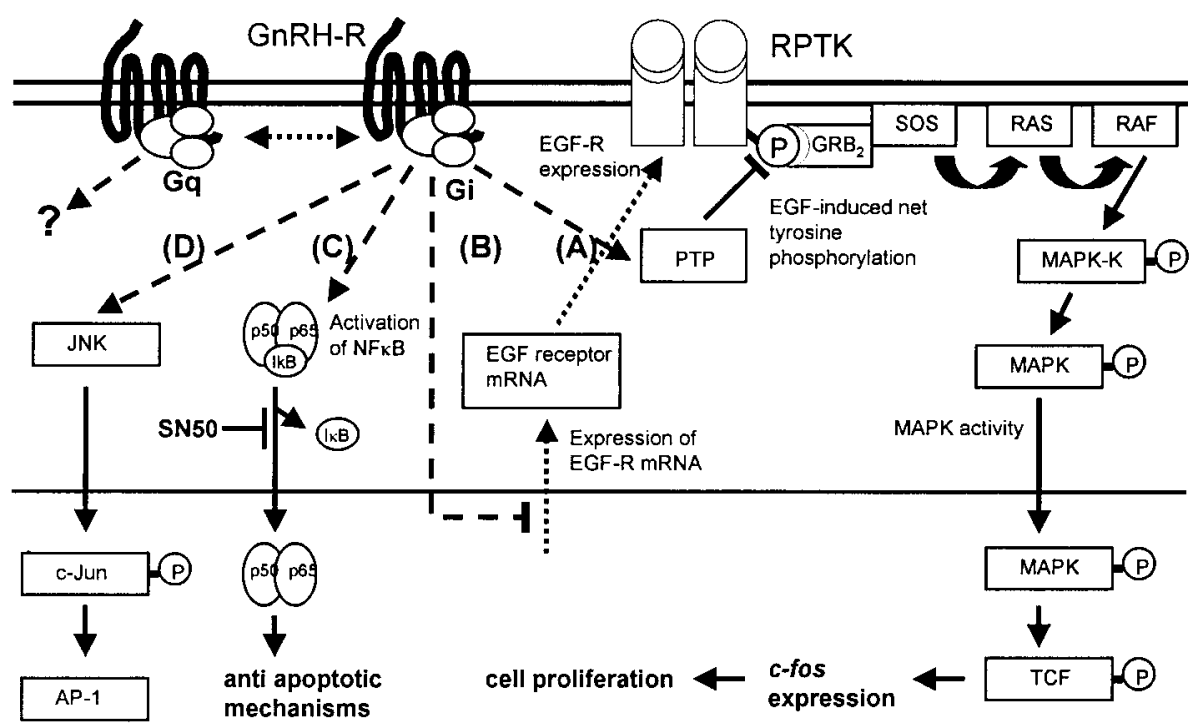

Figure $9 \mathrm{GnRH}$ signaling in gynecological cancer cells. (A) GnRH activates a PTP, which inhibits the mitogenic signal transduction of growth factor, receptors resulting in downregulation of cell proliferation. (B) GnRH downregulates EGF receptor (EGF-R) mRNA

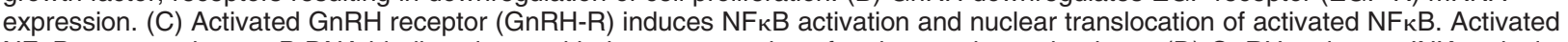
$\mathrm{NF}_{\kappa B}$ now couples to $\mathrm{\kappa B}$ DNA binding sites and induces expression of antiapoptotic mechanisms. (D) GnRH activates JNK and stimulates AP-1 activity. In gynecological cancer cells, GnRH analogs mediate antiproliferative actions via inhibition of growthfactor-induced mitogenic signal transduction. In addition, GnRH induces growth factor receptor downregulation. GnRH protects the cancer cells from apoptosis via activation of NFKB, and stimulates AP-1 and JNK activity. RPTK, Receptor protein tyrosine kinase; TCF, transcription factor; IкB, inhibitory $\kappa \mathrm{B} ; \mathrm{Gq}$, G-protein $\alpha \mathrm{q} ; \mathrm{Gi}$, G-protein $\alpha \mathrm{i}$; SN50, inhibitor of nuclear translocation of activated NF $\mathrm{kB}$; p50, p65, NFKB subunits. For references and further details see text.

the GnRH receptors are linked to the G-protein $\alpha \mathrm{i}-$ cAMP signal transduction pathway. Fig. 9 summarizes current knowledge on GnRH signal transduction in gynecological cancers.

The existence of the additional GnRH-II system in brain, pituitary and reproductive organs, and in tumors of these organs, together with knowledge of different mechanisms of action in these tissues, may contribute to the development of new GnRH agonists and antagonists having selective actions on these different $\mathrm{GnRH}$ receptors and systems. For example, new selective GnRH analogs could be developed that inhibit endometriosis without affecting pituitary gonadotrophs. Other selective GnRH analogs developed for assisted reproduction might downregulate pituitary gonadotroph function without having effects on the endometrium. The use of selective $\mathrm{GnRH}$ receptor modulators might improve the therapeutic efficacy of $\mathrm{GnRH}$ analogs.

\section{References}

1 Schally AV. Hypothalamic hormones from neuroendocrinology to cancer therapy. Anticancer Drugs 19945 115-130.

2 Stojilkovic SS \& Catt KJ. Expression and signal transduction pathways of gonadotropin-releasing hormone receptors. Recent Progress in Hormone Research 199530 161-205.
3 Stanislaus D, Pinter JH, Janovick JA \& Conn PM. Mechanisms mediating multiple physiological responses to gonadotropinreleasing hormone. Molecular and Cellular Endocrinology 1998 $1441-10$.

4 Emons G \& Schally AV. The use of luteinizing hormone-releasing hormone agonists and antagonists in gynecological cancers. Human Reproduction 19949 1364-1379.

5 Imai A, Iida K \& Tamaya T. Tight coupling of gonadotropinreleasing hormone receptor to stimulated phosphoinositide turnover and antigonadotropic action in granulosa cells. Gynecologic and Obstetric Investigation 199233 36-41.

6 Leung PC \& Steele GL. Intracellular signaling in the gonads. Endocrine Reviews 199213 476-498.

7 Stojilkovic SS, Reinhart J \& Catt KJ. GnRH receptors: structure and signal transduction pathways. Endocrine Reviews 199415 $462-499$.

8 Ohno T, Imai A, Furui T, Takahashi K \& Tamaya T. Presence of gonadotropin-releasing hormone and its messenger ribonucleic acid in human ovarian epithelial carcinoma. American Journal of Obstetrics and Gynecology 1993169 605-610.

9 Harris N, Dutlow C, Eidne K, Dong KW, Roberts J \& Millar RP. Gonadotropin-releasing hormone gene expression in MDA-MB231 and ZR-75-71 breast carcinoma cell lines. Cancer Research $1991512577-2581$

10 Hsueh AJ \& Jones PB. Extrapituitary actions of gonadotropinreleasing hormone. Endocrine Reviews 19812 437-461.

11 Merz WE, Erlewein C, Licht P \& Harbarth P. The secretion of human chorionic gonadotropin as well as the $\alpha$ - and $\beta$-messenger ribonucleic acid levels are stimulated by exogenous gonadoliberin pulses applied to first trimester placenta in a superfusion culture system. Journal of Clinical Endocrinology and Metabolism 199173 84-92.

12 Lin LS, Roberts VJ \& Yen SS. Expression of human gonadotropinreleasing hormone receptor gene in placenta and its functional 
relationship to human chorionic gonadotropin secretion. Journal of Clinical Endocrinology and Metabolism $1995 \mathbf{8 0} 580-585$.

13 Bramley TA, McPie CA \& Menzies GS. Human placental gonadotropin-releasing hormone $(\mathrm{GnRH})$ binding sites: I. Characterization, properties and ligand specifity. Placenta $199213555-581$.

14 Bramley TA, McPhie CA \& Menzies GS. Human placental gonadotropin-releasing hormone $(\mathrm{GnRH})$ binding sites: III. Changes in $\mathrm{GnRH}$ binding levels with stage of gestation. Placenta 199415 733- 745 .

15 Fraser HM, Sellar E, Illingworth PJ \& Eidne KA. GnRH receptor mRNA expression by in situ hybridization in the primate pituitary and ovary. Molecular Human Reproduction 19962 117-121.

16 Peng C, Fan NC, Ligier M, Väänänen J \& Leung PCK. Expression and regulation of gonadotropin-releasing hormone $(\mathrm{GnRH})$ and $\mathrm{GnRH}$ receptor messenger ribonucleic acids in human granulosa-luteal cells. Endocrinology 1994135 1740-1745.

17 Minaretzis D, Jakubowski M, Mortola JF \& Pavlou SN. Gonadotropin-releasing hormone receptor gene expression in human ovary and granulosa-lutein cells. Journal of Clinical Endocrinology and Metabolism $1995 \mathbf{8 0} 430-434$.

18 Chegini N, Rong H, Dou Q, Kipersztok C \& Williams RS. Gonadotropin-releasing hormone $(\mathrm{GnRH})$ and $\mathrm{GnRH}$ receptor gene expression in human myometrium and leiomyomata and the direct action of $\mathrm{GnRH}$ analogs on myometrial smooth muscle cells and interaction with ovarian steroids in vitro. Journal of Clinical Endocrinology and Metabolism 199681 3215-3221.

19 Chen HF, Jeung EB, Stephenson M \& Leung PC. Human peripheral blood mononuclear cells express gonadotropin-releasing hormone (GnRH), GnRH receptor, and interleukin-2 receptor gamma-chain messenger ribonucleic acids that are regulated by GnRH in vitro. Journal of Clinical Endocrinology and Metabolism $199984743-750$.

20 Ho HN, Chen HF, Chen SU, Chao KH, Yang YS, Huang SC et al. Gonadotropin-releasing hormone (GnRH) agonist induces down-regulation of the CD3+CD25+ lymphocyte subpopulation in peripheral blood. American Journal of Reproductive Immunology $199533243-252$.

21 Standaert FE, Chew BP, De Avila D \& Reeves JJ. Presence of luteinizing hormone-releasing hormone binding sites in cultured porcine lymphocytes. Biology of Reproduction 199246 997-1000.

22 Tsutsumi M, Zhou W, Millar RP, Mellon PL, Roberts JL, Flanagan CA et al. Cloning and functional expression of a mouse gonadotropin-releasing hormone receptor. Molecular Endocrinology $199261163-1169$.

23 Kakar SS, Musgrove LC, Devor DC, Sellers JC \& Neill JD. Cloning, sequencing, and expression of human gonadotropin-releasing hormone $(\mathrm{GnRH})$ receptor. Biochemical and Biophysical Research Communications 1992189 289-295.

24 Chi L, Zhou W, Prikhozan A, Flanagan C, Davidson KJS, Golembo $\mathrm{M}$ et al. Cloning and characterization of the human gonadotropin-releasing hormone receptor. Molecular and Cellular Endocrinology 199391 R1-R6.

25 Kakar SS, Grizzle WE \& Neill JD. The nucleotide sequence of human GnRH receptors in breast and ovarian tumors are identical with that found in pituitary. Molecular and Cellular Endocrinology 1994106 145-149.

26 Sealfon SC \& Millar RP. Functional domains of the gonadotropinreleasing hormone receptor. Cellular and Molecular Neurobiology $19951525-42$.

27 Sealfon SC \& Millar RP. The gonadotropin-releasing hormone receptor: structural determinations and regulatory control. Human Reproduction Update 19951 216-230.

28 Campion CE, Turzillo AM \& Clay CM. The gene encoding the ovine gonadotropin-releasing hormone $(\mathrm{GnRH})$ receptor: cloning and initial characterization. Gene $1996 \mathbf{1 7 0} 277-280$.

29 Neer EJ. Heterotrimeric G proteins: organizers of transmembrane signals. Cell $199580249-257$.

30 Heldin $\mathrm{CH}$. Dimerization of cell surface receptors in signal transduction. Cell $1995 \mathbf{8 0} 213-223$.
31 Hsieh KP \& Martin TFJ. Thyrotropin-releasing hormone and gonadotropin-releasing hormone receptors activate phospholipase $\mathrm{C}$ by coupling to the guanosine triphosphate-binding proteins Gq and G11. Molecular Endocrinology 19926 1673-1681.

32 Nathwani PS, Kang SK, Cheng KW, Choi KC \& Leung PC. Regulation of gonadotropin-releasing hormone and its receptor gene expression by 17 beta-estradiol in cultured human granulosaluteal cells. Endocrinology 2000141 1754-1763.

33 Kang SK, Tai CJ, Nathwani PS, Choi KC \& Leung PC. Stimulation of mitogen-activated protein kinase by gonadotropin-releasing hormone in human granulosa-luteal cells. Endocrinology 2001 $142671-679$.

34 Chiang CH, Cheng KW, Igarashi S, Nathwani PS \& Leung PC. Hormonal regulation of estrogen receptor alpha and beta gene expression in human granulosa-luteal cells in vitro. Journal of Clinical Endocrinology and Metabolism 200085 3828-3839.

35 Srkalovic G, Schally AV, Wittliff JL, Day TG Jr \& Jenison EL. Presence and characteristics of receptors for [D-Trp6]luteinizing hormone releasing hormone and epidermal growth factor in human ovarian cancer. International Journal of Oncology 1998 12 489-498.

36 Kang SK, Choi KC, Cheng KW, Nathwani PS, Auersperg N \& Leung PC. Role of gonadotropin-releasing hormone as an autocrine growth factor in human ovarian surface epithelium. Endocrinology 2000141 72-80.

37 Reshkin SJ, Albarani V, Pezetta A, Marinaccio M \& Paradiso A. Gonadotrophin releasing hormone $(\mathrm{GnRH})$ receptor and steroid receptors in human uterine leiomyoma, myometrium and endometrium. International Journal of Oncology 2001 (In Press).

38 Ikeda M, Taga M, Kurogi K \& Minaguchi H. Gene expression of gonadotropin-releasing hormone, but not its receptor, in human endometrium and decidua. Molecular and Cellular Endocrinology $1997135165-168$.

39 Raga F, Casan EM, Kruessel JS, Wen Y, Huang HY, Nezhat C et al. Quantitative gonadotropin-releasing hormone gene expression and immunohistochemical localization in human endometrium throughout the menstrual cycle. Biology of Reproduction 1998 $59661-669$.

40 Casan EM, Raga F, Bonilla-Musoles F \& Polan ML. Human oviductal gonadotropin-releasing hormone: possible implications in fertilization, early embryonic development, and implantation. Journal of Clinical Endocrinology and Metabolism $2000 \mathbf{8 5}$ 1377-1381.

41 Borroni R, Di Blasio AM, Gaffuri B, Santorsola R, Busacca M, Vigano P et al. Expression of GnRH receptor gene in human ectopic endometrial cells and inhibition of their proliferation by leuprolide acetate. Molecular and Cellular Endocrinology 2000 $15937-43$.

42 Kottler ML, Starzec A, Carre MC, Lagarde JP, Martin A \& Counis $\mathrm{R}$. The genes for gonadotropin-releasing hormone and its receptor are expressed in human breast with fibrocystic disease and cancer. International Journal of Cancer 71 595-599.

43 Friess H, Buchler M, Kiesel L, Krüger M \& Beger HG. LHRH receptors in the human pancreas. Basis for antihormonal treatment in ductal carcinoma of the pancreas. International Journal of Pancreatology $1991 \mathbf{1 0} 151-159$.

44 Baumann KH, Kiesel L, Kaufmann M, Bastert G \& Runnebaum B. Characterization of binding sites for a GnRH-agonist (buserelin) in human breast cancer biopsies and their distribution in relation to tumor parameters. Breast Cancer Research and Treatment 1993 $2537-46$.

45 Dondi D, Limonta P, Moretti RM, Marelli MM, Garattini E \& Motta M. Antiproliferative effects of luteinizing hormonereleasing hormone (LHRH) agonists on human androgen-independent prostate cancer cell line DU 145: evidence for an autocrine-inhibitory LHRH loop. Cancer Research $1994 \mathbf{5 4}$ 4091-4095.

46 Loop SM, Gorder CA, Lewis SM, Saiers JH, Drivdahl RH \& Ostenson RC. Growth inhibition of human prostatic cancer cells by an agonist of gonadotropin-releasing hormone. Prostate 199526 179-188. 
47 Gründker C \& Emons G. GnRH - mechanisms of action. In GnRH Analogues, The State of the Art at the Millennium, pp 95-120. Ed. B Lunenfeld. Carnforth: Parthenon Publishing 1999.

48 Imai A, Ohno T, Iida K, Fuseya T, Furui T \& Tamaya T. Gonadotropin-releasing hormone receptors in gynecological tumors. Cancer $1994742555-2561$.

49 Imai A, Ohno T, Iida K, Fuseya T, Furui T \& Tamaya T. Presence of gonadotropin-releasing hormone receptor and its messenger ribonucleic acid in endometrial carcinoma and endometrium. Gynecologic Oncology 199455 114-118.

50 Irmer G, Bürger C, Müller R, Ortmann O, Peter U, Kakar S et al. Expression of the messenger RNAs for luteinizing hormonereleasing hormone $(\mathrm{LHRH})$ and its receptor in human ovarian epithelial carcinoma. Cancer Research 199555 817-822.

51 Emons G, Ortmann O, Becker M, Irmer G, Springer B, Laun R et al. High affinity binding and direct antiproliferative effects of LHRH analogues in human ovarian cancer cell lines. Cancer Research $1993545439-5446$.

52 Emons G, Schröder B, Ortmann O, Westphalen S, Schulz KD \& Schally AV. High affinity binding and direct antiproliferative effects of luteinizing hormone-releasing hormone analogs in human endometrial cancer cell lines. Journal of Clinical Endocrinology and Metabolism 199377 1458-1464.

53 Fekete M, Wittliff JL \& Schally AV. Characteristics and distribution of receptors for [D-Trp6]-luteinizing hormone-releasing hormone, somatostatin, epidermal growth factor and sex steroids in 500 biopsy samples of human breast cancer. Journal of Clinical Laboratory Analysis 19893 137-147.

54 Harris N, Dutlow C, Eidne K, Dong KW, Roberts I \& Millar RP. Gonadotropin-releasing hormone gene expression in MDA-MB231 and ZR-75-71 breast carcinoma cell lines. Cancer Research $1991512577-2581$.

55 Ohno T, Imai A, Furui T, Takahashi K \& Tamaya T. Presence of gonadotropin-releasing hormone and his messenger ribunucleic acid in human ovarian epithelial carcinoma. American Journal of Obstetrics and Gynecology 1993169 605-610.

56 Irmer G, Bürger C, Ortmann O, Schulz KD \& Emons G. Expression of luteinizing hormone-releasing hormone and its mRNA in human endometrial cancer cell lines. Journal of Clinical Endocrinology and Metabolism 199479 916-919.

57 Yano T, Pinski J, Radulovic S \& Schally AV. Inhibition of human epithelial ovarian cancer cell growth in vitro by agonistic and antagonistic analogues of luteinizing hormone-releasing hormone. PNAS 199491 1701-1704.

58 Miller WR, Scott WN, Morris R, Fraser HM \& Sharpe RM. Growth of human breast cancer cells inhibited by luteinizing hormonereleasing hormone agonist. Nature 1985313 231-233.

59 Shibata S, Sato H, Ota H, Karube A, Takahashi O \& Tanaka T. Involvement of annexin $\mathrm{V}$ in antiproliferative effects of gonadotropin-releasing hormone agonists on human endometrial cancer cell line. Gynecologic Oncology $199766217-221$.

60 Emons G, Ortmann O, Schulz KD \& Schally AV. Growth-inhibitory actions of analogues of luteinizing hormone releasing hormone on tumor cells. Trends in Endocrinology and Metabolism 19978 155-362.

61 Yano T, Pinski J, Halmos G, Szepeshazi K \& Schally AV. Inhibition of growth of OV-1063 human epithelial ovarian cancer xenografts in nude mice by treatment with luteinizing hormonereleasing hormone antagonist SB-75. PNAS $1994917090-7094$.

62 Thompson MA, Adelson MD \& Kaufman LM. Lupron retards proliferation of ovarian tumor cells cultured in serum-free medium. Journal of Clinical Endocrinology and Metabolism $1991 \mathbf{7 2}$ $1036-1041$

63 Kleinman D, Douvdevani A, Schally AV, Levy J \& Sharoni Y. Direct growth inhibition of human endometrial cancer cells by the gonadotropin-releasing hormone antagonist SB-75: role of apoptosis. American Journal of Obstetrics and Gynecology 1994 170 96-102.

64 Pályi I, Vincze B, Kálnay A, Turi G, Mezo I, Teplan I et al. Effect of gonadotropin releasing hormone analogs and their conjugates on gonadotropin-releasing hormone receptor-positive human cancer cell lines. Cancer Detection and Prevention 199620 146-152.

65 Connor JP, Buller RE \& Conn PM. Effects of GnRH analogs on six ovarian cancer cell lines in culture. Gynecologic Oncology 1994 $543215-3221$.

66 Manetta A, Gamboa-Vujicic L, Paredes P, Emma D, Liao S, Leong L et al. Inhibition of growth of human ovarian cancer in nude mice by luteinizing hormone-releasing hormone antagonist Cetrorelix (SB-75). Fertility and Sterility $199563282-287$.

67 Chatzaki E, Bax CMR, Eidne KA, Anderson L, Grudzinskas JG \& Gallagher CJ. The expression of gonadotropin-releasing hormone and its receptor in endometrial cancer and its relevance as an autocrine growth factor. Cancer Research $1996 \mathbf{5 6}$ 2055-2065.

68 Emons G, Ortmann O, Irmer G, Müller V, Schulz KD \& Schally AV. Treatment of ovarian cancer with LHRH antagonists. In Treatment with GnRH Analogs: Controversies and Perspectives, pp 165-172. Eds M Filicori \& C Flamigni. Carnforth: Parthenon Publishing, 1996.

69 Motta M, Dondi D, Moretti M, Montagnani-Marelli M, Pimpinelli $\mathrm{F}$, Maggi R et al. Role of growth factors, steroid and peptide hormones in the regulation of human prostatic tumor growth. Journal of Steroid Biochemistry and Molecular Biology $1996 \mathbf{5 6}$ 107-111.

70 Jungwirth A, Galvan G, Pinski J, Halmos G, Szepeshazi K, Cai RZ et al. Luteinizing hormone releasing hormone antagonist Cetrorelix (SB-75) and bombesin antagonist RC-3940-II inhibit the growth of androgen-independent $\mathrm{PC}-3$ prostate cancer in nude mice. Prostate 199732 164-172.

71 Jungwirth A, Pinski J, Galvan G, Halmos G, Szepeshazi K, Cai RZ et al. Inhibition of growth of androgen-independent DU-145 prostate cancer in vivo by luteinizing hormone-releasing hormone antagonist Cetrorelix and bombesin antagonists RC-3940-II and RC-3950-II. European Journal of Cancer $1997331141-1148$.

72 Montagnani-Marelli M, Moretti RM, Dondi D, Limonta P \& Motta M. Effects of LHRH agonists on the growth of human prostatic tumor cells: 'in vitro' and 'in vivo' studies. Archives of Italian Urology and Andrology $199769257-263$.

73 Qayum A, Gullick W, Clayton RC, Sikora K \& Waxman J. The effects of gonadotropin-releasing hormone analogues in prostate cancer are mediated through specific tumor receptors. British Journal of Cancer 199062 96-99.

74 Emons G, Weiß S, Ortmann O, Gründker C \& Schulz KD. Luteinizing hormone-releasing hormone (LHRH) might act as a negative autocrine regulator of proliferation of human ovarian cancer. European Journal of Endocrinology 2000142 665-670.

75 Arencibia JM \& Schally AV. Luteinizing hormone-releasing hormone as an autocrine growth factor in ES-2 ovarian cancer cell line. International Journal of Oncology 200016 1009-1013.

76 Emons G, Müller V, Ortmann O, Grossmann G, Trautner U, von Stuckrad B et al. Luteinizing hormone-releasing hormone agonist triptorelin antagonizes signal transduction and mitogenic activity of epidermal growth factor in human ovarian and endometrial cancer cell lines. International Journal of Oncology 19969 1129-1137.

77 Moretti RM, Montagnani-Marelli M, Dondi D, Poletti A, Martini L, Motta $\mathrm{M}$ et al. Luteinizing hormone-releasing hormone agonists interfere with the stimulatory actions of epidermal growth factor in human prostatic cancer cell lines, LNCaP and DU 145. Journal of Clinical Endocrinology and Metabolism $1996 \mathbf{8 1}$ 3930-3937.

78 Shirahige Y, Cook C, Pinski J, Halmos G, Nair R \& Schally AV. Treatment with luteinizing hormone-releasing hormone antagonist SB-75 decreases levels of epidermal growth factor receptor and its mRNA in OV-1063 human epithelial ovarian cancer xenografts in nude mice. International Journal of Oncology 1994 5 1031-1035.

79 Kéri G, Balogh A, Szöke B, Téplan J \& Csika O. Gonadotropinreleasing hormone analogues inhibit cell proliferation and acti- 
vate signal transduction pathways in MDA-MB-231 human breast cancer cell lines. Tumor Biology $19911261-67$.

80 Lee MT, Liebow C, Kramer AR \& Schally AV. Effects of epidermal growth factor and analogues of luteinizing hormone-releasing hormone and somatostatin on phosphorylation of tyrosine residues of specific substrates in various tumors. PNAS $1991 \mathbf{8 8}$ $1656-1660$.

81 Liebow C, Lee MT, Kramer AR \& Schally AV. Regulation of luteinizing hormone-releasing hormone receptor binding by heterologous receptor-stimulated tyrosine phosphorylation. PNAS $1991882244-2248$.

82 Hershkovitz E, Marbach M, Bosin M, Levy J, Roberts C Jr, Le Roith $\mathrm{D}$ et al. Luteinizing hormone-releasing hormone antagonists interfere with autocrine and paracrine growth stimulation of MCF-7 mammary cancer cells by insulin like growth factors. Journal of Clinical Endocrinology and Metabolism $1993 \mathbf{7 7}$ 963-968.

83 Imai A, Takagi H, Furui T, Horibe S, Fuseya T \& Tamaya T. Evidence for coupling of phosphotyrosine phosphatase to gonadotropin-releasing hormone receptor in ovarian carcinoma membrane. Cancer 199677 132-137.

84 Furui T, Imai A, Takagi H, Horibe S, Fuseya T \& Tamaya T. Phosphotyrosine phosphatase activity in membranes from endometrial carcinoma. Oncology Reports 19952 1055-1057.

85 Imai A, Takagi H, Horibe S, Fuseya T \& Tamaya T. Coupling of gonadotropin releasing hormone receptor to $\mathrm{Gi}$ protein in human reproductive tract tumors. Journal of Clinical Endocrinology and Metabolism 199681 3249-3253.

86 Gründker C, Völker P, Günthert AR \& Emons G. Antiproliferative signaling of LHRH in human endometrial and ovarian cancer cells through G-protein $\alpha \mathrm{i}$-mediated activation of phosphotyrosine phosphatase. Endocrinology 2001142 2369-2380.

87 Hunter T. Protein kinases and phosphatases: the yin and yang of protein phosphorylation and signaling. Cell $1995 \mathbf{8 0}$ 222-236.

88 Gründker C, Völker P, Schulz KD \& Emons G. Luteinizing hormonereleasing hormone (LHRH) agonist triptorelin and antagonist cetrorelix inhibit EGF-induced $c$-fos expression in human gynecological cancers. Gynecologic Oncology 200078 194-202.

89 Montagnani-Marelli M, Moretti RM, Dondi D, Motta M \& Limonta P. Luteinizing hormone-releasing hormone agonists interfere with mitogenic activity of the insulin-like growth factor system in androgen-independent prostate cancer cells. Endocrinology $1999140329-334$.

90 Cook JV, Faccenda E, Anderson L, Couper GG, Eidne KA \& Taylor PL. Effects of Asn87 and Asp318 mutations on ligand binding and signal transduction in the rat GnRH receptor. Journal of Endocrinology $1993139 \mathrm{R} 1-\mathrm{R} 4$.

91 Zhou W, Flanagan C, Ballesteros JA, Konvicka K, Davidson JS, Weinstein $\mathrm{H}$ et al. A reciprocal mutation supports helix 2 and helix 7 proximity in the gonadotropin-releasing hormone receptor. Molecular Pharmacology 199445 165-170.

92 Davidson JS, Flanagan CA, Zhou W, Becker II, Elario R, Emeran $\mathrm{W}$ et al. Identification of N-glycosylation sites in the gonadotropin-releasing homone receptor: role in receptor expression but not ligand binding. Molecular and Cellular Endocrinology $1995107241-245$.

93 Fan NC, Peng C, Krisinger J \& Leung PC. The human gonadotropin-releasing hormone receptor gene: complete structure including multiple promotors, transcription initiation sites, and polyadenylation signals. Molecular and Cellular Endocrinology $1995107 \mathrm{R} 1-\mathrm{R} 8$.

94 Clapham DE. Direct G-protein activation of ion channels? Annual Review of Neurosciences $199417441-464$.

95 Sharif M, Sasakawa N \& Hanley MR. Malignant transformation by $\mathrm{G}$ protein-coupled hormone receptors. Molecular and Cellular Endocrinology $1994 \mathbf{1 0 0} 115-119$.

96 Strader CD, Fong TM, Tota MR, Underwood D \& Dixon RA. Structure and function of $\mathrm{G}$ protein-coupled receptors. Annual Review of Biochemistry $1994 \mathbf{6 3} 101-132$.
97 Kottler ML, Bergametti F, Carre MC, Morice S, Decoret E, Lagarde JP et al. Tissue-specific pattern of variant transcripts of the human gonadotropin-releasing hormone receptor gene. European Journal of Endocrinology $1999 \mathbf{1 4 0} 561-569$

98 Imai A, Horibe S, Takagi A, Ohno T \& Tamaya T. Frequent expression of Fas in gonadotropin-releasing hormone receptorbearing tumors. European Journal of Obstetrics and Gynecology and Reproductive Biology 1997 74 73-78.

99 Imai A, Takagi A, Horibe S, Takagi H \& Tamaya T. Evidence for tight coupling of gonadotropin-releasing hormone receptor to stimulate Fas ligand expression in reproductive tumors: possible mechanism for hormonal control of apoptotic cell death. Journal of Clinical Endocrinology and Metabolism 199883 127-431.

100 Imai A, Takagi A, Horibe S, Takagi H \& Tamaya T. Fas and Fasligand system may mediate antiproliferative activity of gonadotropin-releasing hormone receptor in endometrial cancer cells. International Journal of Oncology $19981397-100$.

101 Gründker C, Schulz K, Günthert AR \& Emons G. Luteinizing hormone-releasing hormone induces nuclear factor kappaBactivation and inhibits apoptosis in ovarian cancer cells. Journal of Clinical Endocrinology and Metabolism 200085 3815-3820.

102 Gründker C, Schlotawa L, Viereck V \& Emons G. Protein kinase Cindependent stimulation of activator protein-1 and c-Jun Nterminal kinase activity in human endometrial cancer cells by LHRH agonist triptorelin. European Journal of Endocrinology 2001 $145651-658$.

103 Yamauchi J, Itoh H, Shinoura H, Miyamoto Y, Hirasawa A, Kaziro Y et al. Involvement of c-Jun N-terminal kinase and p38 mitogen-activated protein kinase in $\alpha 1 \mathrm{~B}$-adrenergic receptor/ Gaq-induced inhibition of cell proliferation. Biochemical and Biophysical Research Communications 2001281 1019-1023.

104 Bigsby RM \& Li A. Differentially regulated immediate early genes in the rat uterus. Endocrinology $19941341820-1826$.

105 Seppänen M, Lin L, Punnonen J, Grénman S, Punnonen R \& Vihko K. Regulation of UT-OC-3 ovarian carcinoma cells by cytokines: inhibitory effects on cell proliferation and activation of transcription factors AP-1 and NF-кB. European Journal of Endocrinology 2000142 393-401.

106 Imai A, Furui T, Tamaya T \& Mills GB. A gonadotropin-releasing hormone-responsive phosphatase hydrolyses lysophosphatidic acid within the plasma membrane of ovarian cancer cells. Journal of Clinical Endocrinology and Metabolism $2000 \mathbf{8 5}$ $3370-3375$.

107 Miyamoto K, Hasegawa Y, Nomura M, Igarashi M, Kangawa K \& Matsuo H. Identification of the second gonadotropin-releasing hormone in chicken hypothalamus: evidence that gonadotropin secretion is probably controlled by two distinct gonadotropinreleasing hormones in avian species. PNAS $1984 \quad \mathbf{8 1}$ 3874-3878.

108 Sower SA, Chiang YC, Lovas S \& Conlon JM. Primary structure and biological activity of a third gonadotropin-releasing hormone from lamprey brain. Endocrinology 1993132 $1125-1131$.

109 White RB, Eisen JA, Kasten TL \& Fernald RD. Second gene for gonadotropin-releasing hormone in humans. PNAS 199895 305-309.

110 Urbanski HF, White RB, Fernald RD, Kahoma SG, Garyfallou VT \& Densmore VS. Regional expression of mRNA encoding a second form of gonadotropin-releasing hormone in the macaque brain. Endocrinology $19991401945-1948$.

111 Kang SK, Tai CJ, Nathwani PS \& Leung PC. Differential regulation of two forms of gonadotropin-releasing hormone messenger ribonucleic acid in human granulosa-luteal cells. Endocrinology $2001142182-192$.

112 Neill JD, Duck LW, Sellers JC \& Musgrove LC. A gonadotropinreleasing hormone $(\mathrm{GnRH})$ receptor specific for $\mathrm{GnRH}$ II in primates. Biochemical and Biophysical Research Communications $20012821012-1018$.

113 Tensen C, Okuzawa K, Blomenrohr M, Rebers F, Leurs R, Bogerd J et al. Distinct efficacies for two endogenous ligands on a single 
cognate gonadoliberin receptor. European Journal of Biochemistry 1997243 134-140.

114 Blomenrohr M, Heding A, Sellar R, Lewis R, Bogerd J, Eidne KA et al. Pivotal role for the cytoplasmic carboxyl-terminal tail of a nonmammalian gonadotropin-releasing hormone receptor in cell surface expression, ligand binding, and receptor phosphorylation and internalization. Molecular Pharmacology 199956 $1229-1237$.

115 Sun YM, Flanagan CA, Illing N, Ott TR, Sellar R, Fromme BJ et al. A chicken gonadotropin-releasing hormone receptor that confers agonist activity to mammalian antagonists. Identification of D-Lys(6) in the ligand and extracellular loop two of the receptor as determinants. Journal of Biological Chemistry 2001276 $7754-7761$

116 Karande AA, Rajeshwari K, Schol DJ \& Hilgers JH. Establishment of immunological probes to study human gonadotropin-releasing hormone receptors. Molecular and Cellular Endocrinology 1995 114 51-56.

Received 22 June 2001

Accepted 6 September 2001 